\title{
The Eerdmans Dictionary of Early Judaism
}

\section{Collins, John J \& Harlow, Daniel C (eds.)}

Grand Rapids, MI/Cambridge, UK: Eerdmans 2010

Pages: xxxvii +1360

ISBN 978-0-8028-2549-0 (US\$95.00/£62.99)

Reviewed by Louis Jonker

Old and New Testament

Stellenbosch University

$\mathrm{T}$

The upsurge in studies on Second Temple Judaism in the past decades makes the publication of a dictionary focusing on "Early Judaism" no surprise. Since the discovery of the Dead Sea Scrolls and the resurgence of interest in the Pseudepigrapha made a wealth of primary sources available to scholars, Second Temple Judaism has been the focus of many publications and conference papers in the past decades - an interest field which remains in vogue today. The editors of this dictionary express their surprise that "[d] espite the proliferation of studies, however, there has not hitherto existed a major reference work devoted specifically to this period" (p. vi). The publication of this dictionary is therefore a timeous effort.

In the Preface (p. vi), as well as in the first article by John J. Collins, the designation in the title, "Early Judaism", is defined: "In this volume, we are mainly concerned with the evidence for Judaism between the Bible and the Mishnah" (p. 2). The editors take their cue from the Society of Biblical Literature where "Early Judaism" has been "the accepted name for the Judaism of the Hellenistic and early Roman period" (p. vi). The editors therefore state specifically: "The primary focus falls on the period between Alexander the Great in the late fourth century B.C.E. and the Roman emperor Hadrian and the Bar Kokhba Revolt in the early second century C.E." (p. vi). They admit, however, that "[i]t is impossible to study this period ... without taking some account of the Persian period and the postexilic books, on the one hand, and of the subsequent development of rabbinic Judaism, on the other" (p. vi).

The dictionary is more than a reference tool. It starts off with an extensive first part consisting of thirteen major essays which each provides a very useful overview of a particular aspect of Judaism in this period. Among the names of the contributors of essays in this first part are the two editors, Collins and Harlow; themselves, but also other able scholars such as Eugene Ulrich, James Kugel and Lawrence Schiffman. These essays, which in total span about 290 pages, not only provide an update on present scholarship in various subfields of Second Temple studies, but also offer good and accessible introductory information which could benefit undergraduate and postgraduate students alike.

The second part of the dictionary is then dedicated to 520 entries, which are all on average about two to three pages long, on a range of topics pertaining to "Early Judaism". Each entry includes a select bibliography which could assist the reader in finding more material on the specific topic. A very useful feature of the dictionary is that not only is an alphabetical list of entries-is provided in the initial pages of the publication, but also a topical list of entries. This list (pp. xxiv-xxix) enables an alternative way of accessing the 
dictionary. It is possible to explore different entries thematically - something which would have been impossible without this topical list, given the alphabetic organization of entries.

The topical list also indicates the foci chosen for this dictionary. In terms of the literature of the period under review, numerous entries are included on the following topics: Primary languages of the Jews in the Second Temple Period; Secondary Language in which Early Jewish literature is preserved; Literary genres; Biblical texts, versions, and canon; Hebrew Bible (including entries on only those biblical books originating in the Second Temple period); Apocrypha; Pseudepigrapha and Hellenistic Jewish texts; Dead Sea scrolls; Philo of Alexandria; Josephus; Greek and Latin authors on Jews and Judaism; New Testament and Rabbinic literature. The so-called "non-literature articles" deal with the following themes: Groups and dynasties; Groups in society; Social, political, economic and cultural life; Biblical figures in Early Jewish Interpretation; Historical figures; Mythological and primordial figures, places and events; Religious beliefs and influences; Practices; Religious institutions; Jewish revolts; Cities, countries and regions; Archaeology; and Modern interpreters of Early Judaism.

To do justice in a short review such as this to all of the 520 entries in the dictionary would be impossible. However, a spot check of a representative number of entries, as well as a general paging through the publication, convinced me that the entries are well-written and present solid scholarship. The typography of the dictionary is neatly done, and the maps, pictures and diagrams included in some entries, are really useful. The entries are often subdivided with subheadings, which makes them easily accessible and readable. Although the style is scholarly and thorough, very technical information and references as well as Hebrew and Greek script, are avoided in order to communicate to a wider audience. The list of contributors is impressive and includes scholars from a broad spectrum: geographically and theologically/ideologically spoken.

There will surely be readers of this dictionary who will be able to criticize the editors for omitting certain entries. However, when such a reference work focuses on a very specific period, it may take the liberty of excluding certain entries or themes that are more peripheral to the chosen period.

In general, this is a most useful publication which will be of great help to scholars of the Second Temple period, to students who are looking for a concise starting point in their research on related topics, and to lay readers of the Bible who would like to deepen their knowledge of the period "between the Bible and the Mishnah". 